\title{
PEMANFAATAN LIMBAH INDUSTRI KARAGINAN UNTUK MENGHASILKAN PRODUK BERNILAI TAMBAH
}

\author{
Luthfi Assadad*)
}

\begin{abstract}
ABSTRAK
Tingginya permintaan produk rumput laut untuk memenuhi berbagai kebutuhan industri berdampak pada berkembangnya industri pengolahan rumput laut, diantaranya industri karaginan. Hasil samping industri pengolahan rumput laut berupa limbah yang mengandung selulosa, senyawa alkali, senyawa organik serta zat-zat pengotor. Limbah yang tidak ditangani dan dikelola dengan baik dapat mencemari lingkungan dan merugikan kehidupan manusia. Menyikapi hal ini, maka perlu dilakukan usaha untuk memanfaatkan limbah industri karaginan agar tidak mencemari lingkungan dan bermanfaat bagi manusia. Beberapa potensi pemanfaatan limbah industri karaginan antara lain sebagai media pertumbuhan jamur tiram, papan partikel, kertas, pakan ternak, dan pupuk organik.
\end{abstract}

\section{ABSTRACT: The use of the waste of carrageenan industry for added value products. By: Luthfi Assadad}

The rising demands on seaweed products to satisfy the needs of various manufactures have encouraged the development of seaweed industries, including carrageenan. These industries are known to generate chemical waste that contains cellulose, alkali, organic compounds and impurities. Due to improper handling, this waste has been contributing serious environmental issues. Therefore, efforts in waste recycling are urgently required to lessen its severe environmental impacts and to improve its value. This objective has lead to the application of carrageenan waste for the production of oyster mushroom's media, particle board, paper, animal feed, and organic fertilizer.

KEYWORDS: seaweed, carrageenan, waste

\section{PENDAHULUAN}

Rumput laut sebagai bahan pangan maupun non pangan memiliki prospek yang sangat baik untuk dikembangkan karena ekosistem di daratan tidak mampu memenuhi kebutuhan pangan bagi populasi manusia yang meningkat pesat (Angka \& Suhartono, 2000). Produksi rumput laut nasional pada tahun 2005 mencapai 910.636 ton dan meningkat menjadi 1.079.850 ton pada tahun 2006 (Anon., 2007). Tingginya permintaan produk rumput laut untuk memenuhi berbagai kebutuhan industri berdampak pada berkembangnya industri pengolahan rumput laut menjadi produk bahan baku industri pangan maupun non pangan.

Salah satu produk hasil olahan rumput laut adalah karaginan. Karaginan merupakan produk dari rumput laut yang diekstraksi dengan air atau larutan alkali dari spesies rumput laut kelas Rhodophyceae (alga merah). Karaginan diperoleh dari proses pengendapan rumput laut dengan penambahan alkohol, pengeringan, dan penepungan (Winarno, 1996). Hasil pengolahan rumput laut merah tidak hanya menghasilkan karaginan dengan rendemen $23,8-28,5 \%$, namun juga menghasilkan limbah padat dan cair yang mengandung selulosa dan zat-zat lainnya (Uju, 2005).

Produksi rumput laut Euchema sebagai bahan baku karaginan mencapai 94.000 ton pada tahun 2007 (Anon., 2008a), sedangkan proporsi limbah dalam proses pengolahan karaginan berkisar antara $65-70 \%$ sehingga potensi limbah industri karaginan mencapai lebih dari 60.000 ton pertahun. Limbah hasil ekstraksi karaginan terdiri dari dua jenis yaitu limbah padat dengan kandungan berupa selulosa dan limbah cair dengan kandungan senyawa alkali, senyawa organik serta zat-zat pengotor lainnya (Bixler \& Johndro, 2000; Fithriani et al., 2007). Gambar 1 merupakan contoh limbah cair pengolahan karaginan.

\section{PEMANFAATAN LIMBAH INDUSTRI KARAGINAN}

Limbah yang tidak ditangani dan dikelola dengan baik dapat mencemari lingkungan dan merugikan kehidupan manusia. Bahkan beberapa industri pengolahan karaginan menggunakan area yang luas untuk membuang limbah padat yang dihasilkan. Berdasarkan hal tersebut maka perlu dilakukan

\footnotetext{
*) Peneliti pada Balai Besar Riset Pengolahan Produk dan Bioteknologi Kelautan dan Perikanan
} 


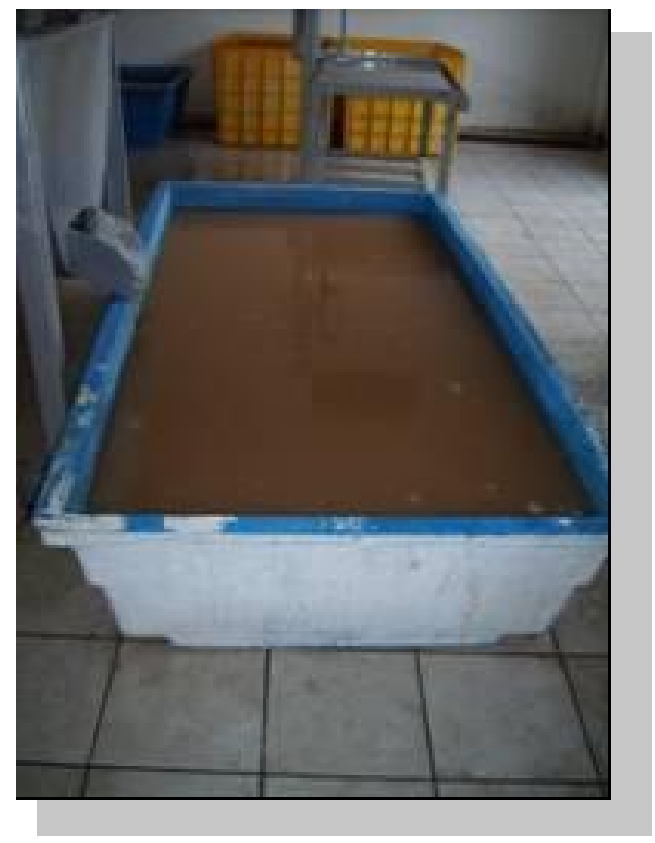

Gambar 1. Limbah cair pengolahan karaginan.

suatu usaha untuk memanfaatkan limbah industri karaginan. Pemanfaatan limbah tersebut dapat mengurangi pencemaran lingkungan dan dapat diolah menjadi produk yang mempunyai nilai tambah. Beberapa potensi pemanfaatan limbah industri karaginan diantaranya sebagai berikut:

\section{Media Pertumbuhan Jamur Tiram}

Jamur tiram merupakan salah satu jenis jamur konsumsi yang dapat tumbuh dengan baik pada berbagai jenis limbah pertanian sekaligus mendegradasi kandungan limbah yang berupa lignoselulosa (Moore \& Chiu, 2002). Di alam, jamur tiram banyak ditemukan tumbuh pada batang kayu yang sudah lapuk. Berdasarkan sifat tumbuh jamur tiram tersebut maka diperkirakan budidaya jamur tiram dapat dilakukan pada media buatan yang mempunyai kandungan hara menyerupai kayu yang sudah lapuk. Bahan baku yang biasa digunakan sebagai media jamur tiram diantaranya serbuk gergaji dan bekatul. Serbuk gergaji digunakan karena memiliki kandungan hara mirip dengan substrat alami jamur (Magingo et al., 2004), sedangkan bekatul digunakan untuk mencukupi kebutuhan nutrisi jamur tiram (Malau, 2004).

Penelitian pembuatan media pertumbuhan jamur tiram dengan memanfaatkan limbah pengolahan karaginan sebagai salah satu bahan penyusun media telah dilakukan (Assadad \& Hardjito, 2009). Selulosa yang terdapat pada limbah industri karaginan merupakan sumber karbon, di mana karbon merupakan salah satu nutrisi yang dibutuhkan oleh jamur tiram (Kaul, 1997). Karbon dibutuhkan untuk menghasilkan energi dan pembentukan struktur sel jamur (Chang \& Miles, 2004). Sumber karbon yang umum digunakan oleh jamur adalah polisakarida, disakarida, monosakarida, asam-asam organik, asamasam amino, alkohol tertentu, komponen-komponen polisiklik dan produk alami lainnya seperti lignin (Miles, 1993). Diagram alir pembuatan media pertumbuhan jamur tiram dengan menggunakan limbah karaginan dapat dilihat pada Gambar 2, sedangkan Gambar 3 merupakan media tumbuh jamur tiram yang telah siap digunakan.

\section{Papan Partikel}

Dengan semakin langkanya bahan baku kayu maka mulai tumbuh kecenderungan untuk memanfaatkan bahan-bahan lain sebagai alternatif dari kayu, misalnya limbah dari industri pertanian (Xu et al., 2004). Pembuatan papan partikel dari limbah padat industri karaginan merupakan salah satu solusi sekaligus sebagai upaya pemanfaatan limbah industri karaginan.

Penelitian yang dilakukan oleh Sedayu et al. (2008) menunjukkan bahwa limbah industri rumput laut memiliki potensi yang baik untuk dijadikan sebagai bahan baku pembuatan papan partikel. Hal ini dapat dilihat dari tingginya kadar selulosa yang terdapat pada limbah industri karaginan. Papan partikel (particle board) adalah papan tiruan yang dibuat dari partikel (serpih) kayu atau bahan selulosa lainnya 


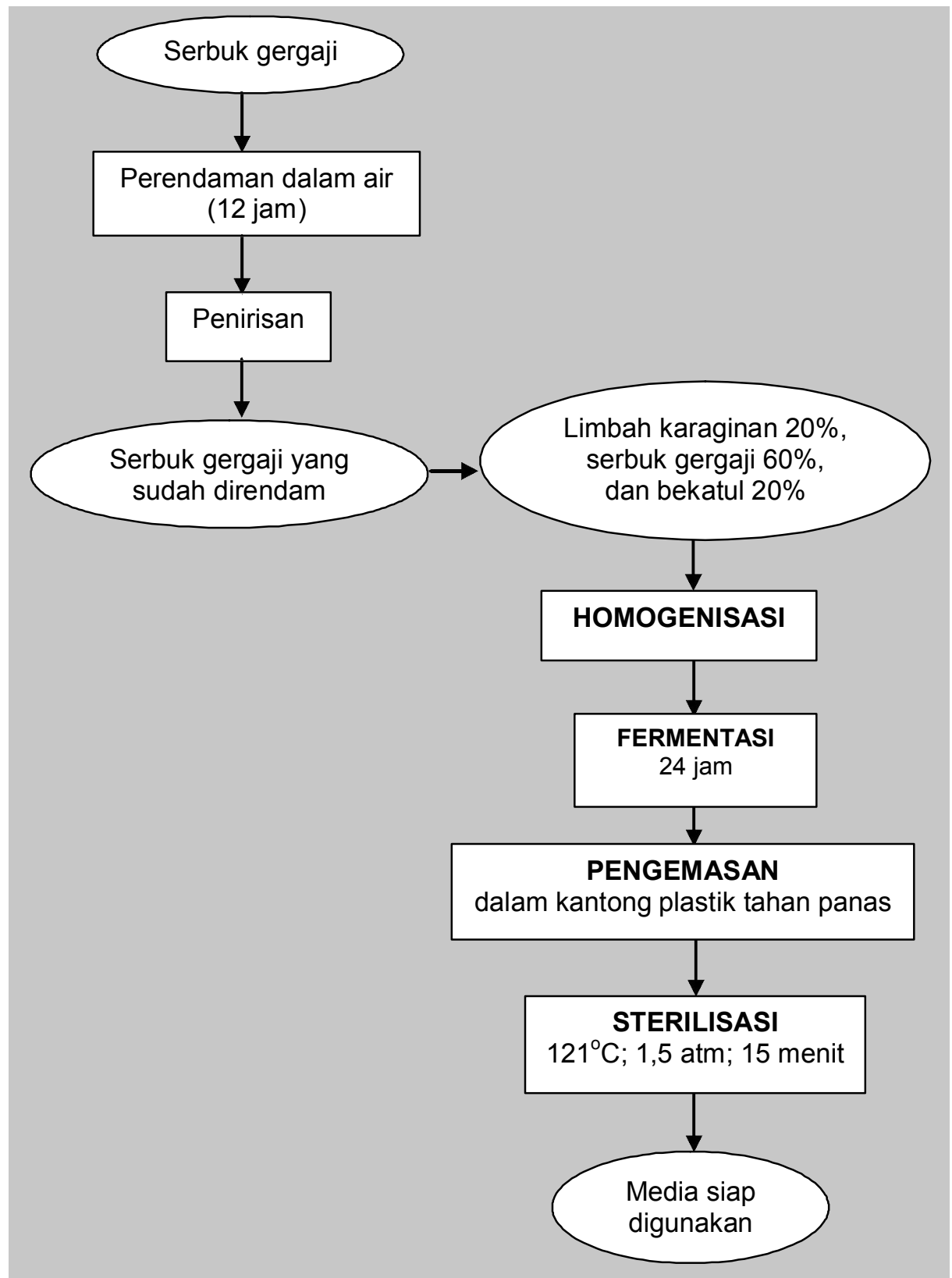

Gambar 2. Diagram alir pembuatan media pertumbuhan jamur tiram (Assadad \& Hardjito, 2009).
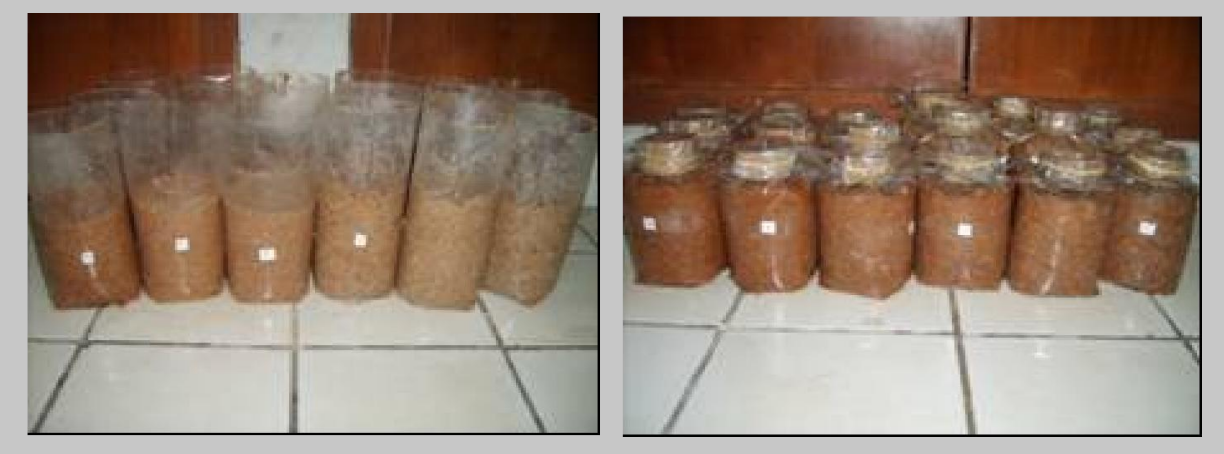

Gambar 3. Media pertumbuhan jamur tiram dari limbah karaginan (Assadad \& Hardjito, 2009). 
yang diikat dengan perekat organik dengan atau tanpa bahan pembantu lainnya melalui proses tekan dan panas (Sutigno, 1994). Jenis papan ini sering digunakan sebagai bahan interior dan eksterior bangunan. Diagram alir pembuatan papan partikel dengan memanfaatkan limbah padat pengolahan rumput laut Gracilaria sp. yang dilakukan Sedayu et al. (2008) dapat dilihat pada Gambar 4.

Hasil penelitian yang dilakukan oleh Sedayu et al. (2008) menunjukkan bahwa papan partikel yang dibuat dari limbah padat rumput laut dengan bahan

\section{Kertas}

Kertas adalah bagian yang tidak terpisahkan dalam kehidupan manusia. Hal ini menyebabkan industri kertas dan pulp (bubur kertas) merupakan salah satu sektor yang memiliki tingkat pertumbuhan yang pesat. Saat ini, Indonesia menempati peringkat ke-9 sebagai produsen pulp dan peringkat ke-12 dalam hal produksi kertas dunia. Di tahun 2010, diperkirakan kebutuhan kertas global akan meningkat 32\% dari 299 juta ton pada tahun 1997 (Silaban, 2008).

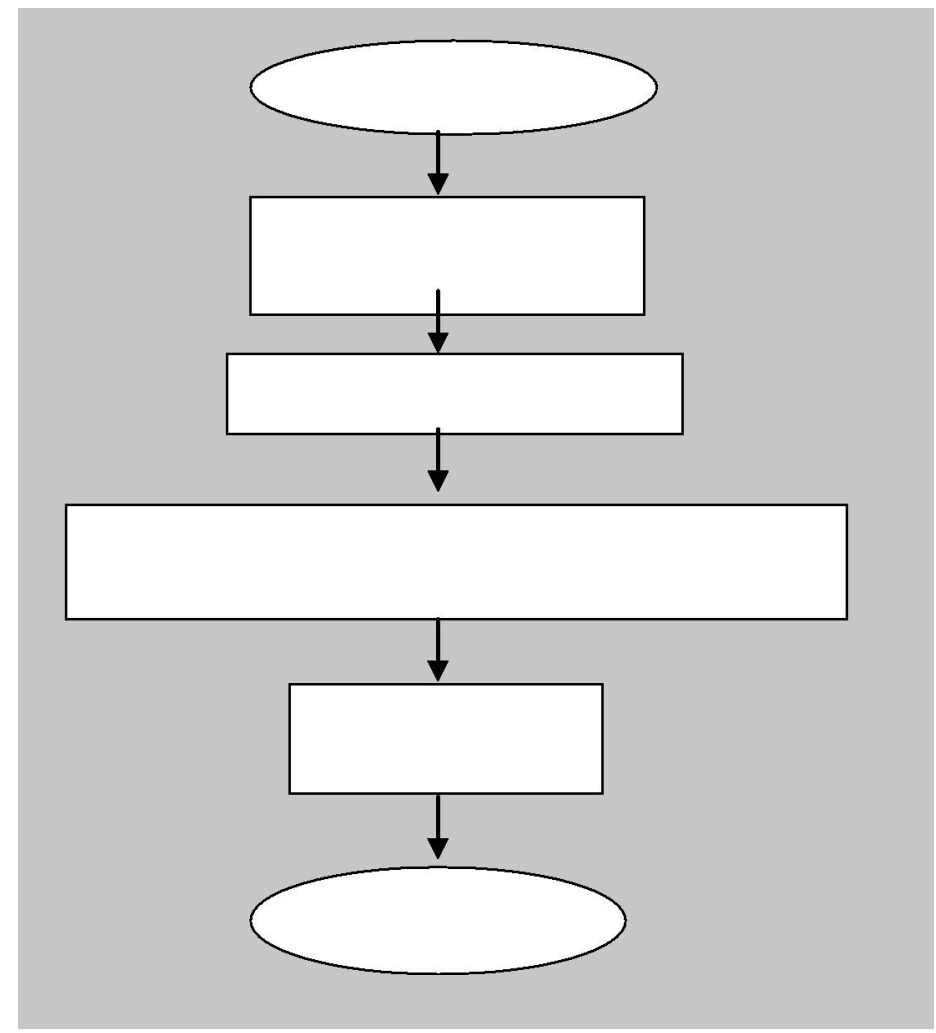

Gambar 4. Diagram alir pembuatan papan partikel (Sedayu et al., 2008).

perekat polietilen memiliki sifat mekanis dengan kekuatan rendah sampai dengan sedang, dengan nilai keteguhan patah (MOR) $58,88-96,78 \mathrm{~kg} / \mathrm{cm}^{2}$ dan keteguhan lentur (MOE) $2,425-6,326 \mathrm{~kg} / \mathrm{cm}^{2}$. Sifat fisik penyerapan air papan partikel yang dihasilkan sangat baik yaitu kurang dari $12 \%$ dengan daya serap air, pengembangan tebal, dan pengembangan linier masing-masing 2,43-3,92\%; 0,00-1,17\%; dan $0,09-1,37 \%$. Nilai keteguhan rekat mencapai $6,41-$ $7,39 \mathrm{~kg} / \mathrm{cm}^{2}$ dan uji rayap $1,55-6,79 \%$. Papan partikel ini dihasilkan dengan perlakuan pengempaan panas selama 3 menit. Mutu papan partikel sendiri dipengaruhi oleh beberapa faktor yaitu jenis bahan baku, ukuran partikel, bahan perekat, dan proses pengolahannya (Sutigno, 1994).
Kertas merupakan salah satu produk turunan kayu. Sebagaimana halnya dengan papan, keberadaan kayu sebagai bahan bakunya semakin langka dewasa ini. Pembuatan kertas dari limbah industri karaginan dapat dipertimbangkan sebagai salah satu alternatif. Beberapa penelitian yang dilakukan menunjukkan bahwa limbah industri rumput laut, termasuk limbah industri karaginan, dapat digunakan sebagai bahan baku pembuatan kertas (Anon., 2009). Hal ini didasarkan pada keberadaan serat pada rumput laut (Silaban, 2008). Hasil penelitian yang dilakukan oleh Nugroho (2007) yaitu pembuatan kertas sebagai pembungkus produk olahan ikan dari rumput laut dengan penambahan kitosan. 
Proses pembuatan kertas dari limbah industri karaginan dimulai dengan mengekstrak karaginan dari rumput laut Euchema, sehingga diperoleh limbah dengan kandungan utama berupa selulosa. Selanjutnya, limbah tersebut diputihkan dan dibuat menjadi bubur kertas, dibentuk sebagai lembaran pada wadah pencetak untuk selanjutnya dipress dan dikeringkan sehingga diperoleh lembaran kertas (Anon., 2008b).

Beberapa kelebihan kertas yang terbuat dari limbah industri karaginan antara lain: proses produksi kertas dari limbah industri karaginan tanpa menggunakan alkali berkonsentrasi tinggi tetapi hanya pemutihan dengan menggunakan bahan pemutih klorin, panjang seratnya seragam sehingga permukaannya lebih halus, serta kerapatan serat yang sangat padat sehingga tidak dibutuhkan materi pengisi di antara serat seperti pada kertas dari kayu (Sutrani, 2009).

\section{Pakan Ternak}

Pakan utama ternak ruminansia adalah hijauan yaitu sekitar $60-70 \%$. Namun demikian karena ketersediaan pakan hijauan sangat terbatas maka pengembangan peternakan dapat diintegrasikan dengan usaha pertanian sebagai strategi dalam penyediaan pakan ternak melalui optimalisasi pemanfaatan limbah pertanian dan limbah industri pertanian (Madyono \& Anggraeni, 2008).

Pemanfaatan limbah sebagai bahan pakan ternak merupakan suatu alternatif bijaksana dalam upaya memenuhi kebutuhan nutrisi yang murah bagi ternak. Dua aspek yang terkait dengan pemanfaatan limbah sebagai pakan ternak adalah ketersediaan bahan baku penyusun ransum bagi ternak dengan nilai ekonomis yang tinggi serta membantu mengurangi pencemaran lingkungan. Limbah sebagai bahan pakan selalu dikaitkan dengan harga yang murah dan kualitas yang rendah, akan tetapi faktanya ada beberapa hal yang perlu diperhatikan sebelum limbah digunakan, seperti ketersediaan, kontinuitas pengadaan, kandungan gizi, kemungkinan adanya faktor pembatas seperti zat racun atau zat anti nutrisi, serta perlu tidaknya bahan diolah sebelum dapat digunakan sebagai pakan ternak (Saputra, 2009).

Limbah industri karaginan dengan kandungan selulosanya dapat dimanfaatkan sebagai pakan ternak. Pada umumnya, limbah ini tidak perlu mendapat perlakuan terlebih dahulu dan langsung diberikan ke hewan ternak. Hal ini dimungkinkan karena hewan ternak seperti ruminansia mempunyai kemampuan untuk mencerna selulosa (Kentjana et al., 2002). Namun demikian untuk meningkatkan nilai gizi pakan ternak dapat diformulasikan dengan limbah perikanan lainnya seperti limbah isi perut, tulang dan kepala ikan, limbah udang, dan lain-lain.

\section{Pupuk Organik}

Pupuk yang berasal dari limbah rumput laut, termasuk di dalamnya limbah industri karaginan, kaya akan unsur hara $\mathrm{Fe}, \mathrm{B}, \mathrm{Ca}, \mathrm{Cu}, \mathrm{Cl}, \mathrm{K}, \mathrm{Mg}$, dan $\mathrm{Mn}$. Hal ini karena rumput laut tumbuh di daerah atau media yang kaya mineral dan terakumulasi di jaringan. Tingginya unsur hara tersebut sangat bermanfaat bagi tanaman dan tanah (Saputra, 2009). Di samping itu, limbah rumput laut juga mengandung zat pengatur tumbuh (ZPT) seperti auksin, sitokinin, giberilin, asam abisat, etilen, P, S, Zn, dan Boron (B) yang dibutuhkan dalam pertumbuhan tanaman (Anon., 2008b). Secara spesifik, fungsi ZPT yaitu meningkatkan produksi buah, sayuran, bunga, dan memperpanjang usia tanaman. Selain itu, ZPT juga dapat meningkatkan daya tahan tanaman dari kekeringan, serangan serangga serta dapat memperbaiki struktur tanah (Anon., 2008c).

Pemanfaatan limbah industri karaginan sebagai pupuk organik juga didukung adanya sifat hidrokoloid pada limbah tersebut yang dapat dimanfaatkan untuk penyerapan air (Molloy et al., 2003). Berdasarkan kandungan mineral dan zat pengatur tumbuh, serta potensi produksi rumput laut jenis Euchema, limbah rumput laut ini diharapkan mampu berkontribusi mensubstitusi kebutuhan pupuk kimia dengan pupuk organik yang berasal dari limbah industri karaginan.

\section{PENUTUP}

Limbah industri karaginan dapat dimanfaatkan untuk menghasilkan produk bernilai tambah secara optimal dan berkelanjutan. Pemanfaatan limbah industri karaginan diharapkan dapat mengurangi berbagai dampak negatif terhadap lingkungan. Limbah industri karaginan dapat dimanfaatkan menjadi produkproduk bernilai ekonomi seperti media pertumbuhan jamur tiram, papan partikel, kertas, dan pupuk organik.

\section{DAFTAR PUSTAKA}

Angka, S.L. dan Suhartono M.T. 2000. Bioteknologi Hasil Laut. Pusat Kajian Sumberdaya Pesisir dan Lautan Institut Pertanian Bogor, Bogor. p. 7-15.

Anonim. 2007. DKP targetkan produksi rumput laut 1,9 juta ton. http://www.dkp.go.id/ content. php?c=4450. Diakses pada tanggal 28 September 2007.

Anonim. 2008a. Indonesia produsen rumput laut terbesar. http://www. dkp.go.id/index.php/ind/news/ 541/indonesia-produsen-rumput-laut-terbesar. Diakses pada tanggal 12 April 2009.

Anonim. 2008b. Peluang nilai tambah rumput laut melalui teknologi kertas. http://blog.lautku.com/2008/ 
01/25/peluang-nilai-tambah-rumput-laut-melaluiteknologi-kertas/. Diakses pada tanggal 26 November 2009.

Anonim. 2009. Gandeng Korea, BPPT teliti rumput laut jadi bahan kertas. http://www.jasuda.net/ index_mbr.php?page=berita_detail\&recordID $=290$ Diaksē pada tanggal 26 November 2009.

Assadad, L. dan Hardjito, L. 2009. Mempelajari pengaruh penggunaan limbah karaginan sebagai media kultivasi jamur tiram (Pleurotus ostreatus). Prosiding Semnaskan VI 25 Juli 2009. Kerjasama Jurusan Perikanan dan Kelautan, UGM dengan Balai Besar Riset Pengolahan Produk dan Bioteknologi Kelautan dan Perikanan dan Indonesian Network on Fish Health Mangement.

Bixler, H.J. and Johndro, K.D. 2000. Philippine natural grade or semi refined carrageenan. In: Phillips. G.O., and Williams, P.A. (eds). Handbooks of Hydrocolloids. CRC Press. Cambridge England.

Chang, S.T. and Miles P.G. 2004. Mushroom: Cultivation, Nutritional Value, Medicinal Effect And Environmental Impact. CRC Press, New York. 451 pp.

Fithriani, D., Sari R.N., dan Sedayu, B.B. 2007. Ekstraksi selulosa dari limbah pembuatan karaginan. J. Pascapanen dan Bioteknologi Kelautan dan Perikanan. 2(2): 91-97.

Kaul, T.N. 1997. Introduction to Mushroom Science (Systematics). Science Publishers Inc., New Hampshire. $198 \mathrm{pp}$.

Kentjana, Y.P., Setiawan Y., dan Endang R.C.C. 2002. Penentuan kondisi optimum pembuatan selulosa asetat untuk bahan membran. Prosiding Seminar Teknologi Selulosa 24 Oktober 2002. Berita Selulosa Vol XXXVII. Balai Besar Penelitian dan Industri Selulosa, Bandung. p. 66-74.

Madyono dan Anggraeny Y.N. 2008. Teknologi pakan murah untuk pembibitan sapi potong di sentra padi. Buletin Sinar Tani Edisi 25 Juni-1 Juli 2008.

Magingo, F.S., Oriyo N.M., Kivaisi A.K., and Danell, E. 2004. Cultivation of Oudemansiella tanzanica nom. Prov. on agricultural solid wastes in Tanzania. J. Mycologia. 96 (2): 197-204.

Malau, L. 2004. Pengaruh penambahan bekatul pada beberapa perlakuan media serbuk gergaji kayu terhadap pertumbuhan dan hasil jamur kuping (Auricularia polytricha (mont.) Sacc.). http:// digilib.uns.ac.id/ pengguna.php? $\mathrm{mn}=$ detail\& d_id=1717. Diakses pada tanggal 4 Juni 2009.

Miles, P.G. 1993. Biological Background for Mushroom Breeding. Gordon and Breach Science Publisher, USA. 324 pp.

Molloy, F.J., Critchley, A.T., Kandjengo, L., and Mshigeni, K.E. 2003. The use of the valuable oyster mushroom, Pleurotus sajor caju, for conversion of waste materials produced from seaweed and brewing industries: Preliminary investigations. J. Ambio. 32(1) 76-78.

Moore, D. and Chiu, S.W. 2002. Impact of developmental, physiological and environmental studies on the commercial cultivation of mushrooms. J. Tropical Mycology Vol 1. Di dalam: Tropical Mycology Macromycetes. CABI Publishing. New York. p.167181.

Nugroho, B.S. 2007. Chitosan-Seaweed Paper. Departemen Teknologi Hasil Perairan, Institut Pertanian Bogor, Bogor. 83 pp.

Saputra, D.R. 2009. Aplikasi Bioteknologi Pemanfaatan Limbah Rumput Laut. Rir Corp. Makassar. 58 pp.

Sedayu, B.B., Widianto T.N., Basmal, J., dan Utomo, B.S.B. 2008. Pemanfaatan limbah padat pengolahan rumput laut Gracilaria sp. untuk pembuatan papan partikel. J. Pascapanen dan Bioteknologi Kelautan dan Perikanan. 3(1): 1-10.

Silaban, I. 2008. Rumput laut, alternatif bahan pembuat kertas. http://suarausu-online.com/web/index. php? option $=$ com_content\&task=vie $w \& i d=126$ Diakses pada tanggal 26 November 2009.

Sutigno, P. 1994. Teknologi papan partikel datar. http:// www.dephut.go.id/Halaman/standardisasi _\&_lingkungan_kehutanan/info_vi02/iv_vi02.htm. Diakses pada tanggal 26 November $200 \overline{9}$.

Sutrani, M. 2009. Kertas dari rumput laut. http://www.iatmicirebon.org/ver.2/ Berita.php? IDKategori= 9\&id=406. Diakses pada tanggal 26 November 2009.

Uju. 2005. Kajian Proses Pemurnian Dan Pengkonsentrasian Karaginan Dengan Membran Mikrofiltrasi. Sekolah Pascasarjana, Institut Pertanian Bogor, Bogor. 114 pp.

Winarno, F.G. 1996. Teknologi Pengolahan Rumput Laut. Pustaka Sinar Harapan, Jakarta. 112 pp.

Xu, X., Zhu, D., Wu, Q., and Vlosky, R.P. 2004. Agro-based composite in China: opportunities and challenges. Forest Products Journal. 54(5): 8-15. 